\title{
THE STRATIGRAPHIC SEQUENCE AT YALÂ (YEMEN): A STATISTICAL EVALUATION
}

\author{
Andrea Manzo \\ University of Naples “L’Orientale.” Email: andreamanzo@virgilio.it.
}

\section{INTRODUCTION}

The South Arabian chronology has been problematic for a long time and this is also a true vexata quaestio for the ancient history of South Arabia. Three different chronologies have been suggested for the first literate phase of South Arabian cultures, which may date to the 11th century BC, the late 8th century BC, or the 5th century BC (see de Maigret 1996:157-63; de Maigret and Robin 1989: 276-8; Pirenne 1988; Robin 1997; Figure 1). At the site of Yalâ, potsherds with incised South Arabian inscriptions have been recovered in a stratum dating at least to the 8th century $\mathrm{BC}$, if not earlier, and offer evidence of the existence of South Arabian culture at that time (de Maigret and Robin 1989:288-9).

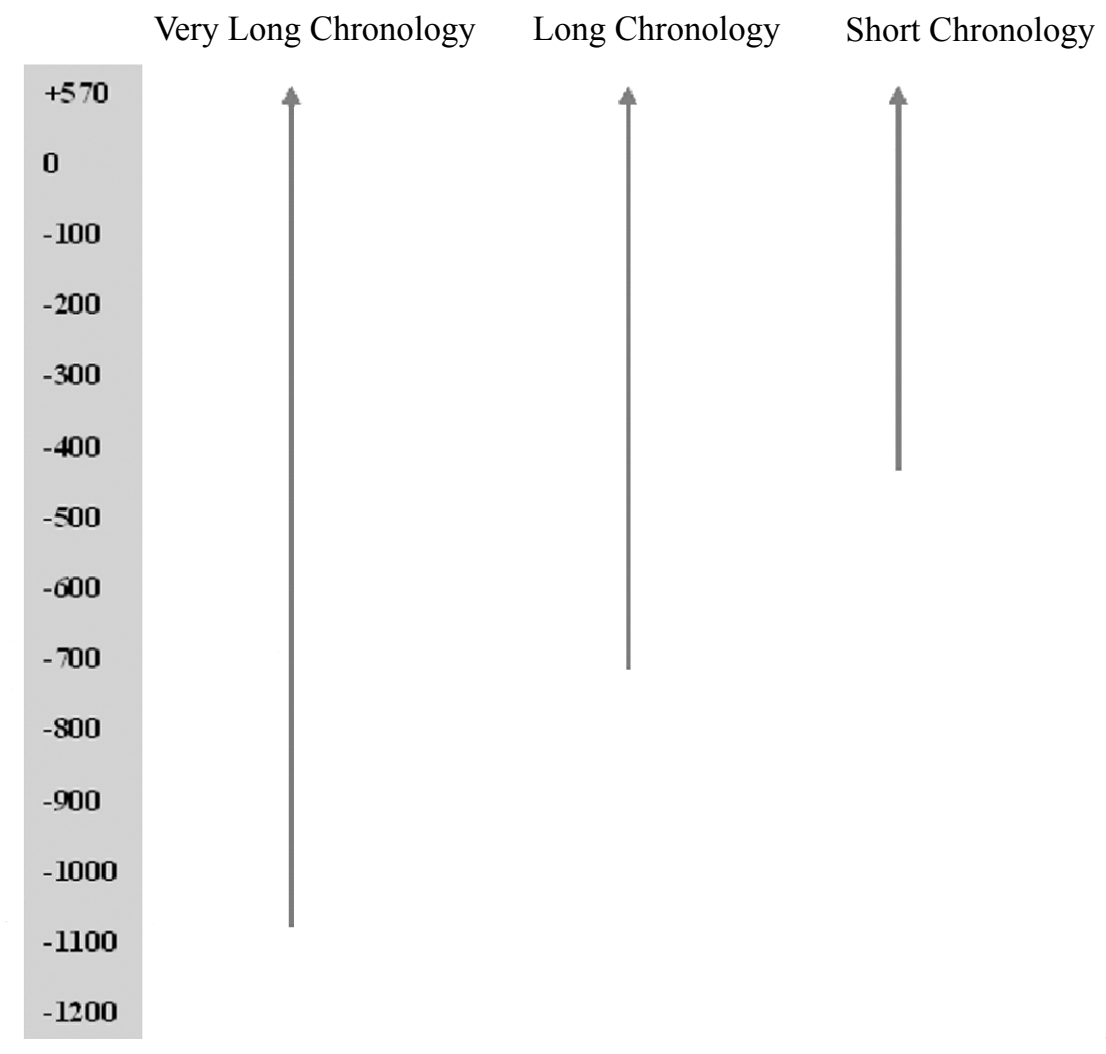

Figure 1 Alternative chronologies for the beginning of the literate phase of South Arabian cultures

\section{RESULTS}

The site of Yalâ - excavated in 1987 by the Italian Archaeological Expedition to Yemen of the Instituto Italiano per il Medio ed Estremo Oriente (IsMEO), led by Alessandro de Maigret—is $30 \mathrm{~km}$ southwest of Ma'rib, the capital of the Sabean kingdom (de Maigret and Robin 1989:278; de Mai- 
gret 1996:163; Figure 2). In an upper sector of the site, an elite Sabean domestic structure (House A) was excavated (de Maigret and Robin 1989:280; de Maigret 1996:163). The walls were well preserved up to a height of $5 \mathrm{~m}$, and the remains of a collapsed first floor were recovered in the room fill (de Maigret and Robin 1989:282; de Maigret 1996:166). Three stratigraphic test-pits were excavated in the rooms under the living-floor of the house, exposing the remains of at least 3 phases of use (phases B, C, and D) under the strata linked to the latest structure (phase A) (de Maigret and Robin 1989:284; de Maigret 1996:170-1).

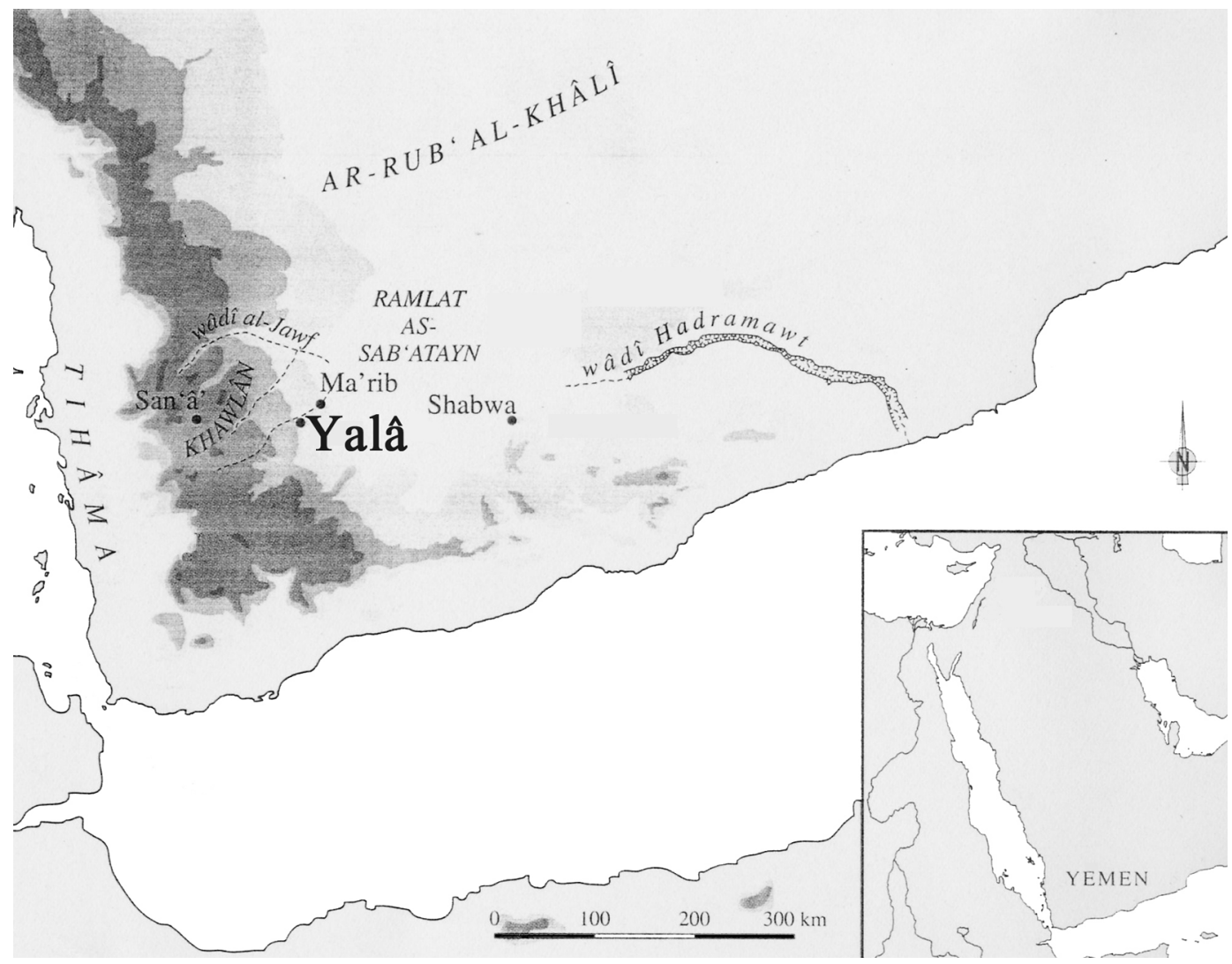

Figure 2 Location of Yalâ in Yemen (modified from Yemen au pays de la Reine de Saba. Paris: Institut de Monde Arabe. 1997. p 23).

The first phase of use of the area (Phase D) is represented by a sequence of occupation layers $\sim 1 \mathrm{~m}$ thick that overlapped the natural fluvial gravel; artifacts were found in these layers but without any traces of structures. The second phase of use (Phase C) is characterized by several occupation layers $\sim 1 \mathrm{~m}$ thick, with traces of a stone wall. The third phase (Phase B) is characterized by several occupation layers $\sim 1.5 \mathrm{~m}$ thick associated with stone structures. The latest occupation phase corresponds to the collapse of the upper floor and to the living-floor of the basement of the House A, the occupation of which ended with a fire (de Maigret and Robin 1989:284-5, Figure 3, Plate 9a-b, Plate $10 \mathrm{a}-\mathrm{b})$.

Five charcoal samples were collected for radiocarbon dating (de Maigret and Robin 1989:286-7, Figure 3; de Maigret 1996:171-2): two from the collapse stratum marking the last phase of use of 
House A, two from a destruction level marking the end of the use of the structures of phase $\mathrm{C}$ and the beginning of phase $\mathrm{B}$, and one from a destruction level at the beginning of phase $\mathrm{C}$. The dates are as follows (de Maigret and Robin 1989:287, note 45, 290):

Phase A (end of the phase)

1 (R 1945a): $2600 \pm 50 \mathrm{BP}$

2 (R 1949a): $2570 \pm 60 \mathrm{BP}$

Phase B (beginning of the phase)

3 (R 1948a): $2750 \pm 75 \mathrm{BP}$

4 (R 1946a): $2840 \pm 70$ BP

Phase $\mathrm{C}$ (beginning of the phase)

5 (R 1947a): $2980 \pm 65$ BP

On the basis of the calibrated ${ }^{14} \mathrm{C}$ dates, the charcoal from House $\mathrm{A}$, and its subsequent abandonment, dates to $850-650 \mathrm{BC}$ and $825-585 \mathrm{BC}$. The charcoal at the beginning of phase $\mathrm{B}$ dates to $1100-795 \mathrm{BC}$ and $1240-830 \mathrm{BC}$, and the charcoal at the beginning of phase $\mathrm{C}$ dates to 1395-920 BC (de Maigret and Robin 1989:287; de Maigret 1996:171-2). If the latest values of calibrated dates and an average period of use of $50 \mathrm{yr}$ for wood are considered, $535 \mathrm{BC}$ and $600 \mathrm{BC}$ are the dates for the end of the last phase of House A, $745 \mathrm{BC}$ for the end of phase B, and $870 \mathrm{BC}$ for the end of phase C (de Maigret and Robin 1989:287-8; de Maigret 1996:172). Thus, phase B, associated with sherds inscribed in South Arabian script (de Maigret and Robin 1989:288), dates to 870-750 BC. Dates for the beginning of phase $\mathrm{C}$ and the underlying phase $\mathrm{D}$, characterized by a Sabean-type pottery (de Maigret and Robin 1989:286; de Maigret 1996:171; de Maigret 1997:51), could not be given precisely.

The importance of the new data from Yalâ has been correctly pointed out by epigraphers trying to date the earliest appearance of the South Arabian script (see Garbini 1995:279-80). Nevertheless, for the sequence of Yalâ and the data from other South Arabian sites, a problem exists in the ${ }^{14} \mathrm{C}$ dates associated with the inscribed sherds due to uncertainties and inconsistencies of the ${ }^{14} \mathrm{C}$ dates, which apparently were considered too old by the excavator who accepted only the more recent calibrated intervals plus an additional period of $50 \mathrm{yr}$ as an average time of wood usage in the buildings (see Garbini 1995:280, note 16; see also p 288, note 41).

Given the importance of the Yalâ sequence for South Arabian archaeology, re-calibration of the ${ }^{14} \mathrm{C}$ dates was done using an updated calibration curve (Stuiver et al. 1998). Moreover, as the Yalâ samples came from a well-established stratigraphic sequence, the OxCal v3.9 program (Bronk Ramsey 2003) was used to evaluate the sequence and its boundaries, mainly focusing on the appearance of inscribed sherds in the sequence. The OxCal v3.9 program allowed the integrated analysis of groups of ${ }^{14} \mathrm{C}$ dates and the inclusion of contextual information, such as stratigraphic and cultural elements, into the calibration and evaluation process by means of Bayesian statistics (Bronk Ramsey 1995, 2000; Buck et al. 1992).

The results of the simple re-calibration of these dates (Stuiver et al. 1998) are as follows: 
$68.2 \%$ probability $(1 \sigma)$ $1370 \mathrm{BC} \quad(2.2 \%) 1350 \mathrm{BC}$ $1320 \mathrm{BC}(64.5 \%) 1110 \mathrm{BC}$ $1100 \mathrm{BC} \quad(1.5 \%) 1080 \mathrm{BC}$ $95.4 \%$ probability $(2 \sigma)$ 1390 BC (95.4\%) 1000 BC $99.7 \%$ probability $(3 \sigma)$ 1450 BC (99.7\%) 900 BC

\section{R 1946a}

$2840 \pm 70$ BP

$68.2 \%$ probability $(1 \sigma)$ 1130 BC (68.2\%) 900 BC

$95.4 \%$ probability $(2 \sigma)$ $1220 \mathrm{BC}(95.4 \%) 830 \mathrm{BC}$ $99.7 \%$ probability $(3 \sigma)$ 1400 BC (99.7\%) 800 BC

\section{R 1948a}

$68.2 \%$ probability $(1 \sigma)$ 1000 BC (68.2\%) 820 BC $95.4 \%$ probability $(2 \sigma)$ 1130 BC (95.4\%) 790 BC $99.7 \%$ probability $(3 \sigma)$ $1300 \mathrm{BC}(99.7 \%) 750 \mathrm{BC}$

\section{R 1945a}

$68.2 \%$ probability $(1 \sigma)$ $830 \mathrm{BC}(58.8 \%) 760 \mathrm{BC}$ $680 \mathrm{BC} \quad(5.0 \%) 660 \mathrm{BC}$ $610 \mathrm{BC} \quad(4.4 \%) 590 \mathrm{BC}$ $95.4 \%$ probability $(2 \sigma)$ $900 \mathrm{BC} \quad(1.8 \%) 870 \mathrm{BC}$ 840 BC (61.4\%) $750 \mathrm{BC}$ $720 \mathrm{BC}(32.2 \%) 540 \mathrm{BC}$ $99.7 \%$ probability $(3 \sigma)$ 910 BC (99.7\%) 480 BC

\section{R 1949a}

$68.2 \%$ probability $(1 \sigma)$ $810 \mathrm{BC}(27.7 \%) 750 \mathrm{BC}$ $690 \mathrm{BC} \quad(8.4 \%) 660 \mathrm{BC}$ $650 \mathrm{BC}(32.1 \%) 540 \mathrm{BC}$ $95.4 \%$ probability $(2 \sigma)$ 840 BC (92.7\%) 510 BC 470 BC $(2.7 \%) 410$ BC $99.7 \%$ probability $(3 \sigma)$ 900 BC (99.7\%) 400 BC 
If we plot these results, we have the sequence shown below.

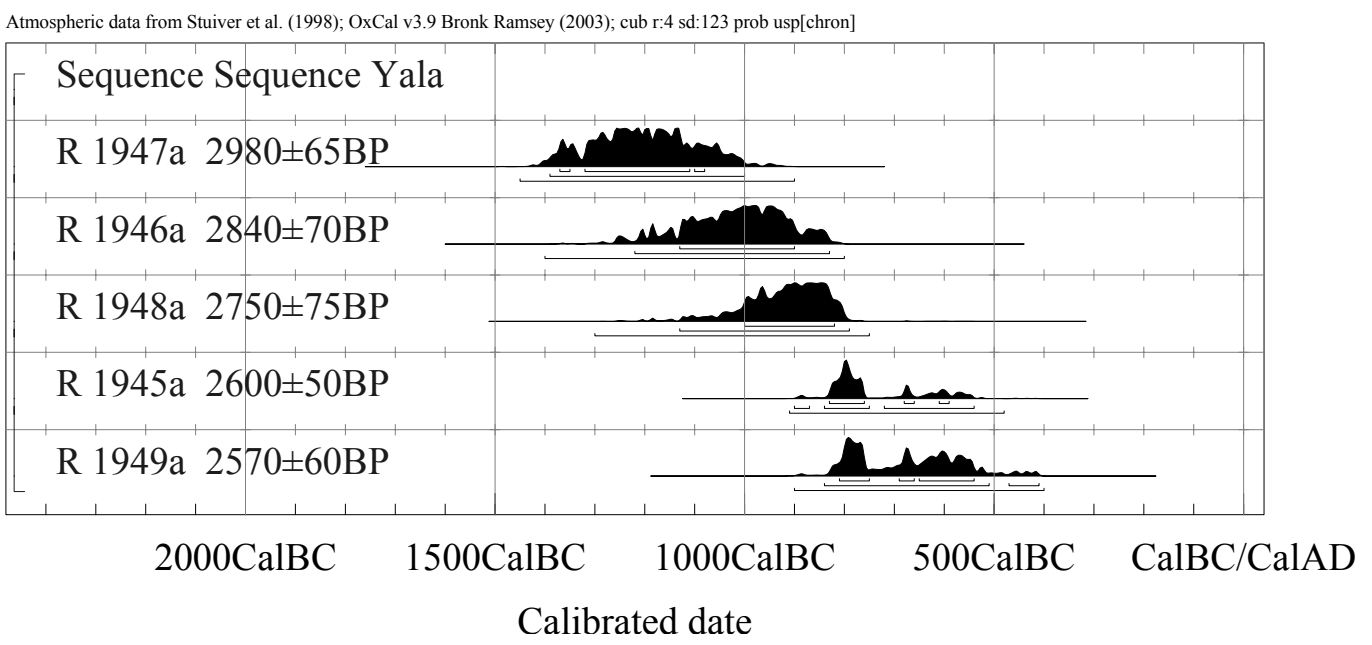

Figure 3 Atmospheric data from Stuiver et al. (1998), OxCal v3.9 Bronk Ramsey (2003)

The stratigraphic relationships of the contexts of the collected samples allows one to evaluate the coherence of the sequence and to derive more narrow dates:

\section{Sampled R 1947a}

$68.2 \%$ probability $(1 \sigma)$

$1260 \mathrm{BC}(68.2 \%) 1040 \mathrm{BC}$

$95.4 \%$ probability $(2 \sigma)$

$1380 \mathrm{BC}(95.4 \%) \quad 990 \mathrm{BC}$

$99.7 \%$ probability $(3 \sigma)$

1410 BC (99.7\%) 920 BC

Agreement 98.2\%

\section{Sampled R 1946a}

$68.2 \%$ probability $(1 \sigma)$

$1030 \mathrm{BC}(63.3 \%) 890 \mathrm{BC}$

$880 \mathrm{BC} \quad(4.9 \%) 850 \mathrm{BC}$

$95.4 \%$ probability $(2 \sigma)$

1110 BC (95.4\%) 820 BC

$99.7 \%$ probability $(3 \sigma)$

1210 BC (99.7\%) 800 BC

Agreement 107.5\%

\section{Sampled R 1948a}

$68.2 \%$ probability $(1 \sigma)$

990 BC (68.2\%) 840 BC

$95.4 \%$ probability $(2 \sigma)$

1050 BC (95.4\%) 800 BC 
$99.7 \%$ probability $(3 \sigma)$

1130 BC (99.7\%) 790 BC

Agreement 104.8\%

Sampled R 1945a

$2600 \pm 50$ BP

$68.2 \%$ probability $(1 \sigma)$

820 BC (68.2\%) 760 BC

$95.4 \%$ probability $(2 \sigma)$

$840 \mathrm{BC}(78.8 \%) 750 \mathrm{BC}$

$710 \mathrm{BC}(16.6 \%) 540 \mathrm{BC}$

$99.7 \%$ probability $(3 \sigma)$

910 BC (99.7\%) 520 BC

Agreement 121\%

Sampled R 1949a

$2570 \pm 60 \mathrm{BP}$

$68.2 \%$ probability $(1 \sigma)$

$830 \mathrm{BC}(64.9 \%) 750 \mathrm{BC}$

$690 \mathrm{BC} \quad(3.3 \%) 660 \mathrm{BC}$

$95.4 \%$ probability $(2 \sigma)$

840 BC (95.4\%) 550 BC

$99.7 \%$ probability $(3 \sigma)$

900 BC (99.7\%) 410 BC

Agreement 124.3\%

Overall agreement $125.6 \%$

It is worth noting that the agreement of each date in the framework of the sequence is always higher than $98 \%$. As a consequence, the overall agreement is very high, having a value higher than $100 \%$. This seems to confirm the coherence of the dates with the stratigraphic context in which the samples were collected.

If the function boundary of the OxCal v3.9 program is used to obtain the end and beginning of the sequence as well as the beginning of the phases, the following results are obtained:

\title{
Sampled Beginning $\mathbf{C}$
}

$68.2 \%$ probability $(1 \sigma)$

$1410 \mathrm{BC}(68.2 \%) 1060 \mathrm{BC}$

$95.4 \%$ probability $(2 \sigma)$

$1700 \mathrm{BC}(95.4 \%) 1000 \mathrm{BC}$

$99.7 \%$ probability $(3 \sigma)$

... $(99.7 \%) 953 \mathrm{BC}$

\section{Sampled Beginning B}

\author{
$68.2 \%$ probability $(1 \sigma)$ \\ 1410 BC (68.2\%) 930 BC \\ $95.4 \%$ probability $(2 \sigma)$ \\ $1250 \mathrm{BC}(95.4 \%) 850 \mathrm{BC}$ \\ $99.7 \%$ probability $(3 \sigma)$ \\ 1400 BC $(99.7 \%) 800 \mathrm{BC}$
}




\section{Sampled Beginning A}

$68.2 \%$ probability $(1 \sigma)$

$900 \mathrm{BC}(68.2 \%) 780 \mathrm{BC}$

$95.4 \%$ probability $(2 \sigma)$

$1000 \mathrm{BC}(95.4 \%) 670 \mathrm{BC}$

$99.7 \%$ probability $(3 \sigma)$

$1100 \mathrm{BC}(99.7 \%) 550 \mathrm{BC}$

\section{Sampled End A}

$68.2 \%$ probability $(1 \sigma)$

810 BC (68.2\%) 570 BC

$95.4 \%$ probability $(2 \sigma)$

$830 \mathrm{BC}(95.4 \%) 340 \mathrm{BC}$

$99.7 \%$ probability $(3 \sigma)$

$850 \mathrm{BC}(99.7 \%)$...

These results can be plotted as follows:

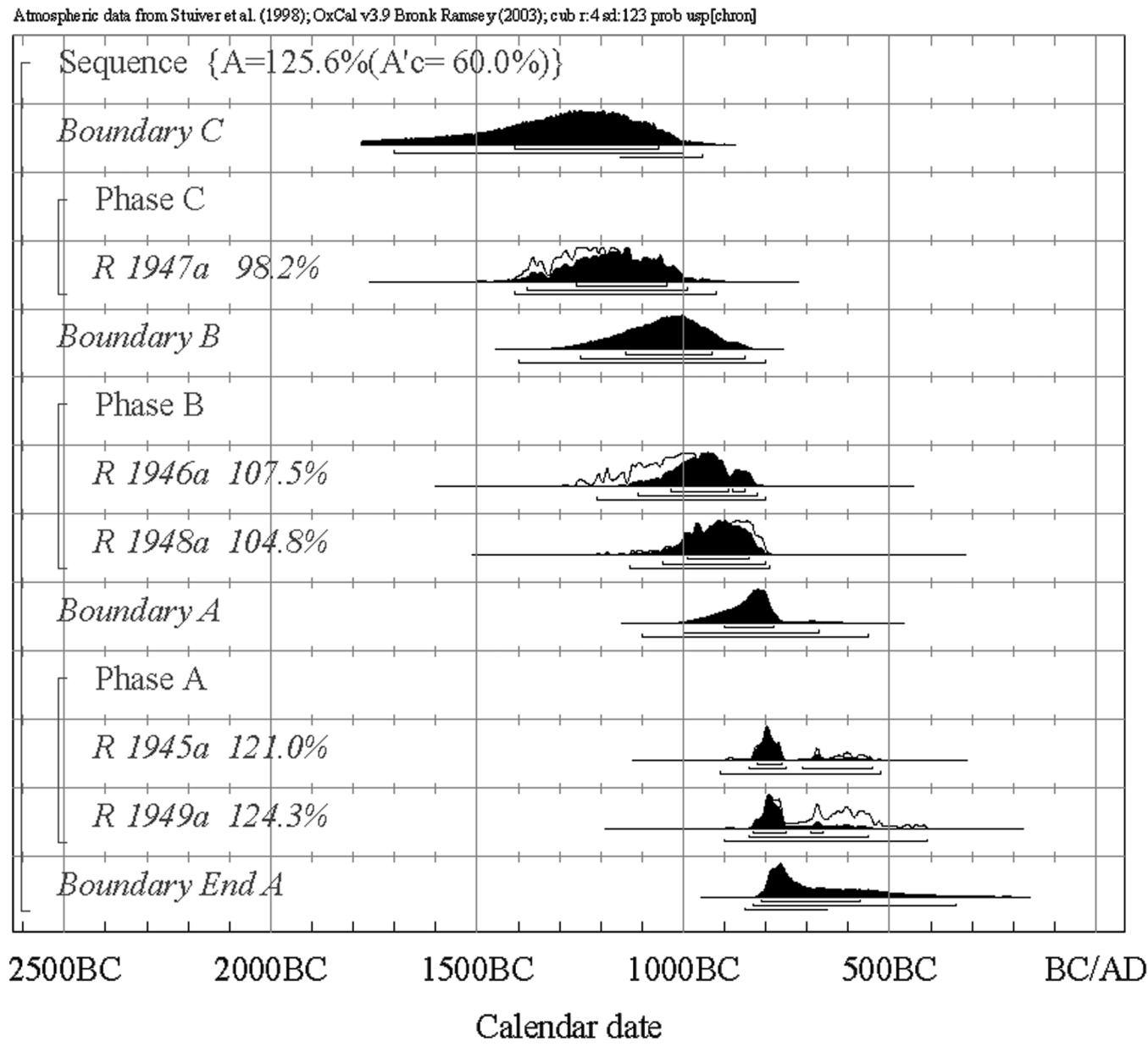

Figure 4 Results of the Yalâ sequence using OxCal v 3.9 
The beginning of sequence $\mathrm{C}$ is as follows:

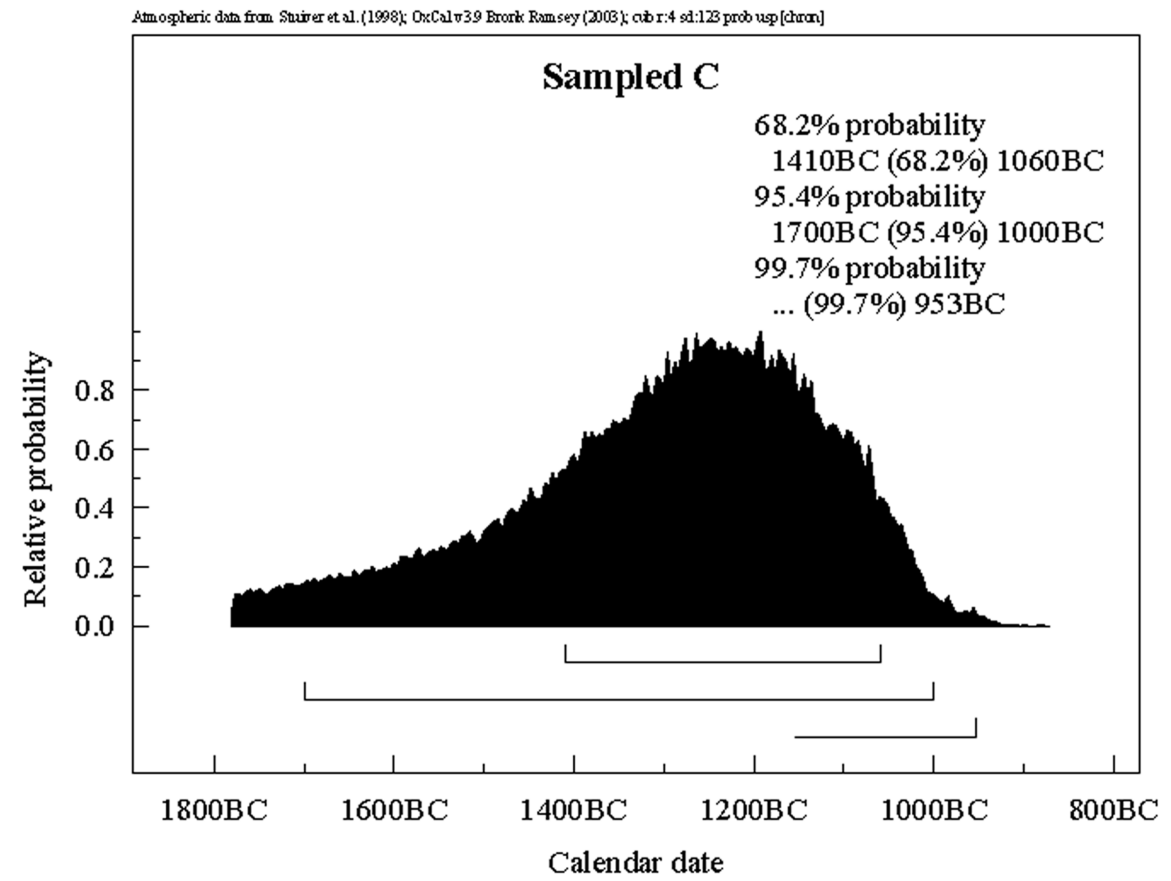

Figure 5 Results for the beginning of sequence $\mathrm{C}$

The beginning of phase B, which contains the inscribed sherds, is as follows:

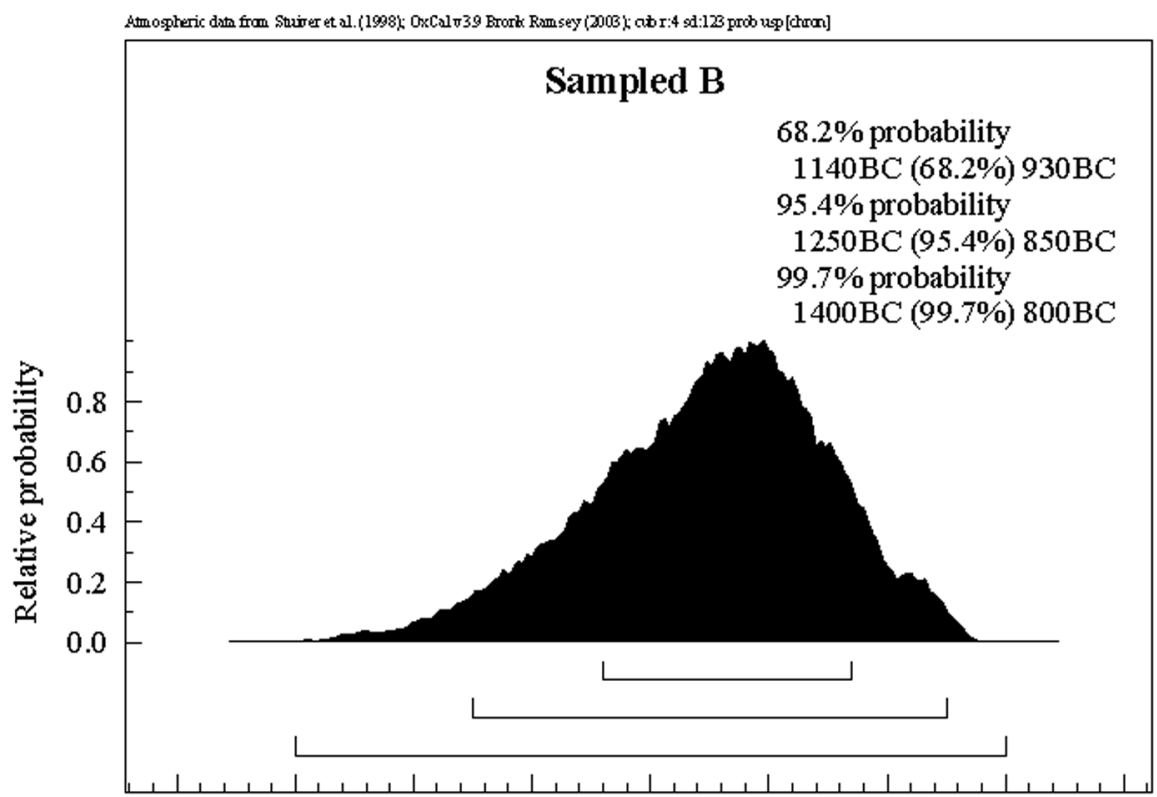

$1500 \mathrm{BC} 1400 \mathrm{BC} 1300 \mathrm{BC} 1200 \mathrm{BC} 1100 \mathrm{BC} 1000 \mathrm{BC} 900 \mathrm{BC} \quad 800 \mathrm{BC} \quad 700 \mathrm{BC}$

Calendar date

Figure 6 Results for the beginning of phase B 
The beginning of phase A, the phase of use of House A, is as follows:

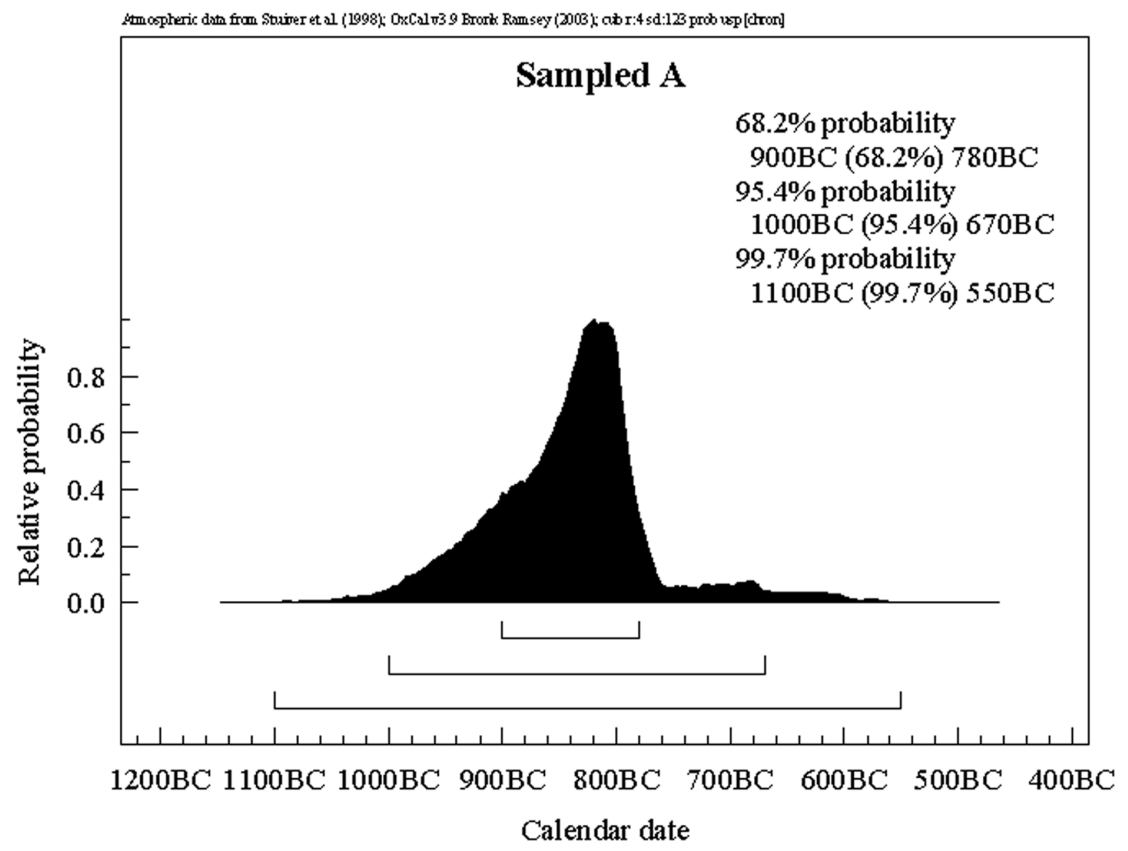

Figure 7 Results for the beginning of phase A

The end of phase A and the sequence is as follows:

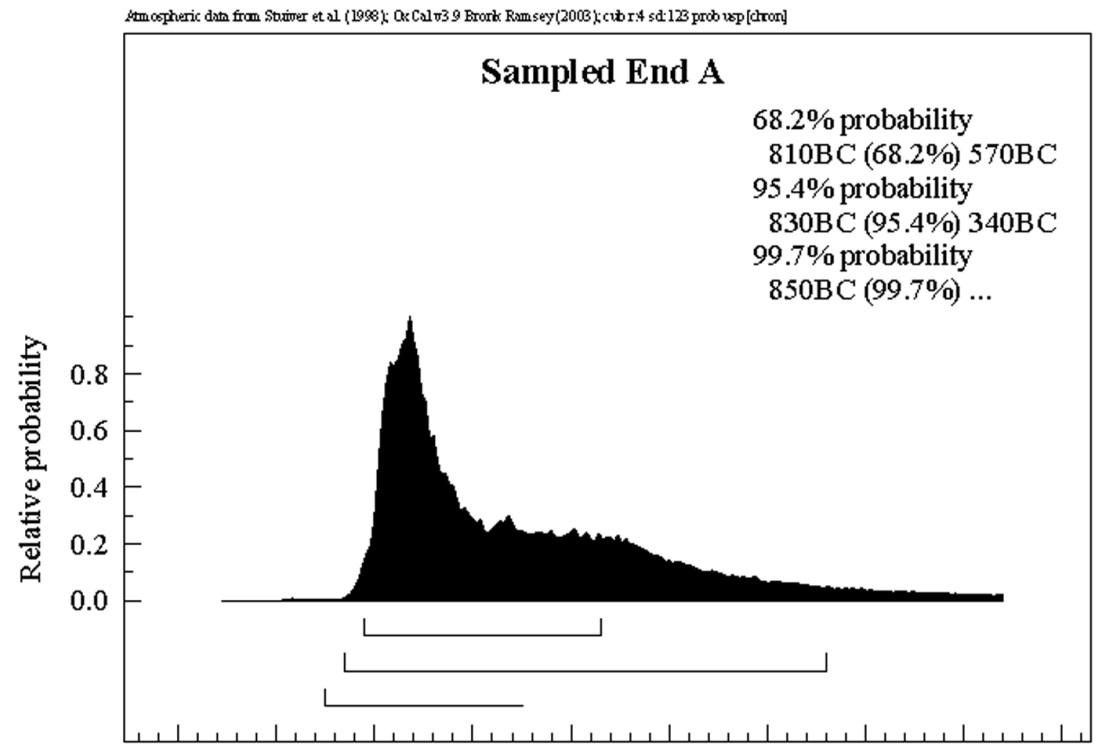

$1000 \mathrm{BC} 900 \mathrm{BC} 800 \mathrm{BC} 700 \mathrm{BC} 600 \mathrm{BC} 500 \mathrm{BC} 400 \mathrm{BC} 300 \mathrm{BC} 200 \mathrm{BC} 100 \mathrm{BC}$ Calendar date

Figure 8 Results for the end of phase A 


\section{DISCUSSION}

As previously noted, 5 samples were collected in the strata associated with the beginning of phase $\mathrm{C}$ (R 1947a), the beginning of phase B (R 1948a, R 1946a), and the end of phase A (R 1945a, R 1949a). Considering the peak of calculated distributions for the boundaries $(1 \sigma)$, the results suggest a length of 130-270 $\mathrm{yr}$ for phase C, 150-240 $\mathrm{yr}$ for phase B, and 90-210 $\mathrm{yr}$ for phase A. Thus, phases $\mathrm{B}$ and $\mathrm{C}$ seem longer than $\mathrm{A}$. Given the previously discussed stratigraphic information, this is fully justifiable since phases $\mathrm{C}$ and $\mathrm{B}$ were characterized by several occupation layers each. On the other hand, phase A corresponds only to the last use of House A.

Regarding the absolute chronology of the phases, since the error in the ${ }^{14} \mathrm{C}$ dates is quite large and the number of determinations is small, it is difficult to define clear boundaries. Nevertheless, considering all of the limitations of the analysis, interesting data are provided on the crucial problem of the origins of the Sabean culture and the date of the earliest South Arabian inscriptions. It is worth noting that in the analysis of the different possible chronologies, reference was made to the extreme higher values obtained from the calibration, and not to the most probable age/interval for the archaeological sequence, in order to outline the shortest possible chronology of the phases.

Moreover, it has correctly been pointed out (de Maigret and Robin 1989:287) that the ${ }^{14} \mathrm{C}$ dates refer to the time of death of the trees and not to the moment when the use of the wood ended, and thus the burned wood used as samples for the ${ }^{14} \mathrm{C}$ dates could have been felled many years before it was burned (de Maigret and Robin 1989:287). Nevertheless, if the charcoal samples come from construction wood, the 50-yr-long period used by de Maigret and Robin (1989:287) might be too brief. Therefore, it was increased to $100 \mathrm{yr}$, but only for the samples of wood apparently associated with collapsed structures, such as those from the last stratum of phase A and those from the destruction stratum at the end of phase $\mathrm{C}$ to the beginning of phase $\mathrm{B}$. This was not done for the sample from the stratum at the beginning of phase $\mathrm{C}$ to the end of phase $\mathrm{D}$ because it came from a layer apparently without any trace of structures, but in this case an average 50-yr period of wood usage was considered.

As a consequence, the beginning of phase $\mathrm{C}$ can be dated before $903 \mathrm{BC}$, which is also a terminus ante quem for the end of the underlying phase $\mathrm{D}$. The beginning of phase $\mathrm{B}$ (i.e. the literate phase) can be dated between 1300 and $700 \mathrm{BC}$. The beginning of phase A (i.e. the phase of use of House A) can be dated between 1000 and $450 \mathrm{BC}$, and the end of phase A is after $750 \mathrm{BC}$. All of these limits are calculated using the maximum probability ( $3 \sigma$, i.e. $99.7 \%$ probability). If we consider the lower possible dates among the ranges with the maximum of probabilities, phase $\mathrm{D}$ can be dated before $903 \mathrm{BC}$, phase $\mathrm{C}$ between 903 and $700 \mathrm{BC}$, phase $\mathrm{B}$ between 700 and $450 \mathrm{BC}$, and phase A after $450 \mathrm{BC}$. The occupation of House A would have ended sometime after $750 \mathrm{BC}$.

Nevertheless, these suggested dates should be accepted with caution. By only taking the lower possible dates with a slightly lower degree of probability ( $2 \sigma$, i.e. $95.4 \%$ probability), phase $\mathrm{D}$ is before $950 \mathrm{BC}$, phase $\mathrm{C}$ between 950 and $750 \mathrm{BC}$, phase $\mathrm{B}$ between 750 and $570 \mathrm{BC}$, and phase $\mathrm{A}$ between 570 and $240 \mathrm{BC}$.

Thus, these dates suggest that the use of the Sabean script is dated to at least the end of the 8th century BC ( $3 \sigma$, i.e. $99.7 \%$ probability), or possibly the mid-8th century BC $(2 \sigma$, i.e. $95.4 \%$ probability). Moreover, the first use of the excavated area at Yalâ can be dated before the end of the 10 th century BC ( $3 \sigma$, i.e. $99.7 \%$ probability), or possibly even before the mid-10th century BC ( $2 \sigma$, i.e. $95.4 \%$ probability). It is worth noting that at that time, the pottery already showed typical Sabean characteristics, which demonstrated that people associated with Sabean material culture were 
present in eastern Hawlân from the beginning of the 10th century BC. In general, these dates are consistent with the evaluations of de Maigret and just a bit later (de Maigret and Robin 1989:2869, see also Garbini, 286-7; Robin 1997:62).

Nevertheless, one cannot exclude the likeliness that the precise dates for the beginning of the archaeological phases at Yalâ are earlier than these dates. If the earliest possible dates for each phase are used, the chronology is higher: phase $\mathrm{D}$ can be dated before $1360 \mathrm{BC}$, phase $\mathrm{C}$ between 1360 and $1300 \mathrm{BC}$, phase B between 1300 and $1000 \mathrm{BC}$, and phase A after $1000 \mathrm{BC}$. The occupation of House A would have ended sometime after $750 \mathrm{BC}$. Using the higher possible dates with a slightly lower degree of probability ( $2 \sigma$, i.e. $95.4 \%$ probability), phase $\mathrm{D}$ can be dated before $1650 \mathrm{BC}$, phase $C$ between 1650 and $1150 \mathrm{BC}$, phase B between 1150 and $900 \mathrm{BC}$, and phase A after $900 \mathrm{BC}$. The occupation of House A would have ended sometime after $730 \mathrm{BC}$.

According to our last chronology, the Sabean script was used in the last centuries of the 2nd millennium BC and a Sabean ceramic tradition was already established in first half of the 2nd millennium BC. Of course, this hypothetical chronological reconstruction cannot support the old "very long chronology," as was elaborated by Eduard Glaser and Friz Hommel (see Hommel 1927), but it seems consistent with that suggested by von Wissmann (1982), which is now widely accepted (de Maigret 1997:51; Robin 1997:63). According to this chronology, a long, but still not clearly determined, period of use of South Arabian script can be hypothesized before the evidence of monumental inscriptions, which also suggests a precocious rise of South Arabian hierarchic society (see Bron 1997:56). Thus, the literate phase could have begun at least in the 12th century BC.

Given the statistical evaluation of the ${ }^{14} \mathrm{C}$ dates from Yalâ, the importance of the stratigraphic sequence of this site for South Arabian archaeology is clear. In both the lowest and highest chronologies that can be proposed, after evaluating the sequence by Bayesian statistics, the results of this study confirm that this well-dated sequence cannot support a "short" or "low" chronology, such as the one proposed by J Pirenne (de Maigret and Robin 1989:288-91). The new chronology also demonstrates the appearance of the South Arabian script in the early 1st millennium BC, or even in the last centuries of the 2nd millennium BC (see also de Maigret 1997:51; Robin 1997:63). Moreover, these dates seem to point to the appearance of a South Arabian ceramic tradition at least in the last centuries of the 2nd millennium BC, or even in the mid-2nd millennium BC - earlier than generally thought. This last hypothesis suggests a possible solution for the chronological gap between the end of the South Arabian Bronze Age in the first half of the 2nd millennium BC and the beginning of Sabean culture (de Maigret 1996:151-2; de Maigret 1997:52).

\section{ACKNOWLEDGMENTS}

I wish to thank Prof de Maigret, University of Naples "L'Orientale" for his suggestions and comments on this paper, and Prof K A Bard, Boston University, for her suggestions and for editing the text. My study of the sequence of ${ }^{14} \mathrm{C}$ dates of Yalâ began in 2002, when I used it as a case study in a seminar on relative and absolute chronology for undergraduate students in the Laboratory of African Archaeology of the University of Naples "L'Orientale."

\section{REFERENCES}

Bron F. 1997. Naissance et destin de l'alphabet sudarabique. In: Yémen au Pays de la Reine de Sabâ. Paris: Institut de Monde Arabe. p 55-7.

Bronk Ramsey C. 1995. Radiocarbon calibration and analysis of stratigraphy: the OxCal program. Radio- carbon 37(2):425-30.

Bronk Ramsey C. 2000. Comment on "The use of Bayesian statistics for ${ }^{14} \mathrm{C}$ dates of chronologically ordered samples: a critical analysis." Radiocarbon 42(2):199-202. 
Bronk Ramsey C. 2003. OxCal 3.9 Program. The Manual. URL: <http://www.rlaha.ox.ac.uk/OxCal3/Manual/oxcal.htm.>

Buck CE, Litton CD, Smith AFM. 1992. Calibration of radiocarbon results pertaining to related archaeological events. Journal of Archaeological Science 19:497-512.

de Maigret A. 1996. Arabia Felix. Un Viaggio Nell'Archeologia dello Yemen. Milan: Rusconi.

de Maigret A. 1997. L'aube de l'histoire dans le Yémen intérieur. In: Yémen au Pays de la Reine de Sabâ. Paris: Institut de Monde Arabe. p 50-2.

de Maigret A, Robin C. 1989. Les fouilles italiennes de Yalâ (Yémen du Nord): nouvelles données sur la chronologie de l'Arabie du sud préislamique. Comptes Rendus de l'Académie des Inscriptions et Belles Lettres. April-June. p 255-91.

Garbini G. 1995. Sulla più antica scrittura sudarabica. Rivista degli Studi Orientali 69:275-94.

Hommel F. 1927. Geschichte Südarabiens im Umriß. In:
Nielsen D, editor. Handbuch der Altarabischen Altertumskunde. Copenhagen: Nyt Nordisk Forlag. p 57108.

Pirenne J. 1988. The chronology of ancient South Arabia - diversity of opinion. In: Daum W, editor. Yemen: 3000 Years of Art and Civilization in Arabia Felix. Innsbruck, and Frankfurt/Main: Penguin-Verlag and Umschau-Verlag. p 116-22.

Robin C. 1997. La chronologie et ses problèmes. In: Yémen au Pays de la Reine de Sabâ. Paris: Institut de Monde Arabe. p 60-2.

Stuiver M, Reimer PJ, Bard E, Beck JW, Burr GS, Hughen KA, Kromer B, McCormac G, van der Plicht J, Spurk M. 1998. IntCal98 radiocarbon age calibration, 24,000-0 cal BP. Radiocarbon 40(3):1041-83.

von Wissmann H. 1982. Die Geschichte von Sabâ, II. Das Großreich der Sebäer bis zu seinen Ende im frühen 4. Jh. v. Chr. Wien: Österreichische Akademie der Wissenschaften Phil.-Hist. Klasse, Sitzungsberichte. p 402. 